\title{
De pretensiones y fracasos: la interpretación poética de la Biblia
}

\author{
J.J. LANERO \\ Universidad de León
}

\section{I}

El presente estudio se centra en la hermenéutica bíblica de Northrop Frye. Su propósito es hacer una interpretación literaria de la Biblia, en contraposición a la teológica, lo que nos daría las razones de por qué un poeta lee los textos bíblicos. Con tal fin, utiliza la tipología desde la creencia de que es capaz de eliminar los elementos teológicos de aquélla en su interpretación literaria más pura de los textos bíblicos. Sin embargo, un análisis más detenido de la tipología nos muestra que, cuando se aplica a la Biblia, como sucede en la obra de Frye, la tipología no puede disociarse de su fundamento teológico. En contra de lo que Frye piensa, que su hermenéutica bíblica no es una interpretación teológica de la imaginería bíblica, nosotros sugerimos que la tipología cristiana es la que define el marco inexorable para la lectura que Frye hace de la Biblia.

Aunque Northrop Frye no se propone que su obra The Great Code sea una lectura teológica de la Biblia, comparte dos principios fundamentales con muchos teólogos cristianos modernos: la valoración negativa de la crítica historicista y el uso de la tipología como hermenéutica bíblica. Muchos teólogos postbarthianos aceptan la descripción que Barth nos ofrece de la forma en la que numerosos críticos historicistas utilizan el concepto de objetividad de la Ilustración. Dentro de lo que podríamos denominar realismo simple, estos críticos piensan que el conocimiento objetivo de la Biblia es posible a través de la erudición histórica. Para ellos la teología se basa en el presupuesto subjetivo de la fe y, por lo tanto, no conduce al conocimiento objetivo. Según Barth, los críticos historicistas hacen caso omiso de sus propios principios ideológicos ${ }^{1}$. El resultado es que la crítica historicista ya no puede considerarse como un empeño objetivo puramente positivista, con lo que da validez a una investigación bíblica fundamentada en la fe. Como tendremos ocasión de ver, la interpretación

${ }^{1}$ Sobre el tema de la crítica de Barth a la crítica histórica, véase B.L. Mc CORMACK, "Historical Criticism and Dogmatic Interest in Karl Barth's Exegesis of the New Testament", en M.S. BURROWS and P. ROREM, eds., Biblical Hermeneutics in Historical Perspective: Studies in Honor of Karlfried Froelich on His SixtyFifth Birthday, Grand Rapids (Eerdmans) 1991, pp.322-338. 


\section{J.L. Lanero}

que Frye hace de los textos bíblicos sigue lo que él mismo denomina erudición bíblica desde una perspectiva tradicional o teológica y no desde la crítica historicista ${ }^{2}$. Para Frye los críticos historicistas se detienen demasiado en la minucia histórica: Textual scholarship has never really developed the higher criticism that made such a noise in the nineteenth century. Instead of emerging from lower criticism, or textual study, most of it dug itself into a still lower, or sub-basement, criticism in which disintegrating the text became an end in itself. As a result its essential discoveries were made quite early, and were followed by a good deal of straw-thrashing ${ }^{3}$.

Para Frye, lo mismo que para muchos teólogos de la actualidad, el coste de la erudición histórica es que su excesivo hincapié en el contexto original de la Biblia anula muchos de sus posibles significados en la sociedad moderna. Podríamos decir que esos posibles significados, cualesquiera que sean, sólo pueden percibirse mediante el estudio de la configuración final de la Biblia.

Además, el interés de Frye por la tipología también coincide con el interés teológico de algunos especialistas por la interconexión entre el Antiguo y el Nuevo Testamento ${ }^{4}$. Frye sostiene que la apreciación tipológica de la Biblia cumple la promesa de comprender lo que es central e importante. En el pasado, la relación entre el Antiguo y Nuevo Testamento se consideraba desde un prisma estacional: el Antiguo Testamento (judío) quedaba relegado a la categoría de preludio del Nuevo (cristiano), ignorando la autonomía de los textos hebreos sin tener que recurrir a la posterior interpretación cristiana. En efecto. La mayor parte de los teólogos cristianos modernos son sensibles a la naturaleza autónoma de la Biblia Hebrea y a la naturaleza compleja de

${ }^{2}$ Northrop FRYE, The Great Code: The Bible and Literature, New York (Harcourt Brace Jovanovich), 1982, p.XVIII. En adelante la citaremos como The Great Code.

${ }^{3}$ Northrop FRYE, The Great Code, ed. cit., p.XVII.

${ }^{4}$ Los ejemplos más significativos los tenemos en J. BARR, The Concept of Biblical Theology, Minneapolis (Fortress), 1999; W. BRUEGGEMANN, The Theology of the Old Testament, Minneapolis (Fortress) 1997; R.P.KNIERIM, The Task of Old Testament Theology, Gran Rapids (W.B. Eerdmans), 1995. Muchos estudiosos bíblicos y teólogos han utilizado, de varias formas, la tipología como hermenéutica bíblica. De especial interés son las obras de A.C. CHARITY, Events and Their Afterlife, Cambridge University Press, 1966; J. DANIÉLOU, From Shadows to Reality: Studies in the Biblical Typology of the Fathers, London (Burns and Oates), 1960; L. Goppelt, Typos, Trans. D. Madvig, Grand Rapids (Eerdmans) 1982. Véanse También los artículos de R.E. MURPHY, "Chistian Understanding of the Old Testament", Theology Digest 18, 1970, 321-32, y de J. WEIR, "Analogous Fulfillment", Perspectives in Religious Studies 9, 1982, 95-176. 
ambos Testamentos. Así las cosas, se nos plantean interrogantes mucho más matizados. No sólo sobre la relación entre la Biblia Hebrea y Cristiana, sino también sobre el yavismo de los primeros israelitas y el posterior desarrollo de los textos judaicos y cristianos. Sin embargo, para Frye, ser consciente de las sutilezas de la relación entre los dos Testamentos no es óbice para entender la Biblia como un todo unificado, y suministra una interpretación más moderna de la tipología. En este contexto, la Biblia se entiende como un Nuevo Testamento que hace realidad las esperanzas del Antiguo.

A pesar de que Frye sostiene que su obra no es teológica, sus objeciones a la critica historicista y al uso de la tipología para interpretar el significado de la Biblia se alinean con algunas vertientes de la teología cristiana moderna. Además, como veremos, la propia tipología, cuando se fundamenta en la idea de dos Testamentos, sólo tiene referencia dentro de un contexto cristiano. Nuestro estudio analiza las justificaciones de Frye para creer que su hermenéutica tipológica no es teología, sino más bien un estudio literario de cómo y por qué un poeta ha de leer la Biblia ${ }^{5}$. En primer lugar, reconstruimos la hermenéutica de Frye, mostrando cuales son sus fines y métodos en la interpretación de los textos bíblicos. En segundo lugar, reconsideramos esa hermenéutica, a la vez que exponemos que la tipología no se puede disociar de la teología cristiana y que la hermenéutica de Frye se basa, necesariamente, en supuestos teológicos cristianos.

\section{II}

La metodología de Frye está expresamente formulada para forjar su propio enfoque de la interpretación bíblica. Los estudios de la Biblia, de hoy y a lo largo de la historia, están dominados bien por la erudición bíblica académica o por la teología. Frye se da cuenta de que su estudio de la Biblia atraviesa campos académicos que no son exclusivamente suyos: A scholar in an area not his own feels like a knight errant who finds himself in the middle of a tournament and has unaccountally left his lance at home ${ }^{6}$. Pero Frye está prevenido. Su interés por la Biblia y el lenguaje bíblico abarca desde los primeros años de su vocación ministerial hasta sus últimos escritos; sobre todo los que versan sobre perspectivas religiosas. Sin embargo, Frye conoce el campo de batalla en el que se adentra y busca protección en un planteamiento claro de su método y de lo que persigue en su interpretación de la Biblia.

\footnotetext{
${ }^{5}$ Northrop FRYE, The Great Code, ed. cit., p.XVIII.

${ }^{6}$ Ibid., p.IX.
} 


\section{J.L. Lanero}

Frye aborda la Biblia como crítico literario, que para él significa estar interesado en cómo y por qué un poeta ha de leerla ${ }^{7}$. Este interés inicial por la Biblia coincide con la tesis general de su teoría literaria. Desde este contexto, la obra de Frye sobre la Biblia debe entenderse como estudio literario de los mitos bíblicos y como último paso para su esbozo de la estructura de la literatura, iniciado en Anatomy of Criticism.

En su interés por la influencia de la Biblia en la literatura inglesa y en el arte, Frye encuentra escaso apoyo en lo que denomina enfoques críticos de los estudios bíblicos, pues entiende que son métodos que persiguen fijar los textos en su contexto histórico: I could not find the clues I wanted in critical Biblical scholarship, so far as I was acquainted with it. The analytical and historical approach that dominated Biblical criticism for over a century was of relatively little use to me, however incidentally I may depend on it. At no point does it throw any real light on how or why a poet might read the Bible ${ }^{8}$.

Frye no distingue entre métodos analíticos e historicistas, pues para él ambos procuran encontrar el contexto histórico de los textos bíblicos. Lo que él adjetiva como analítico e histórico se conoce como método histórico-crítico, siendo su objetivo representar o reconstruir el contexto cultural, social y religioso de cada etapa bíblica. Para los estudiosos histórico-críticos la determinación de los textos bíblicos, el significado original de palabras y frases, y la comprensión del ámbito del que surgieron esos textos es lo que constituye la base del estudio crítico $^{9}$. La inmensa mayoría de estos estudios coincide en que los textos bíblicos guardan una estrecha relación con los acontecimientos históricos y en que comparándolos con la evidencia arqueológica, el estudio lingüístico y otras fuentes extra-bíblicas, se puede obtener una mejor comprensión histórica de las épocas bíblicas y de los textos que éstas produjeron ${ }^{10}$. También existe otro enfoque de la historia bíblica, distinto de la metodología histórico-crítica. Adopta la forma de construir la historiografía de la Biblia. Se considera como una narración exacta y descriptiva de los acontecimientos históricos. El fin último de esta investigación es demostrar que los hechos de los que habla la Biblia corresponden a sucesos históricos reales. Para Frye ambos méto-

${ }^{7}$ Ibid., p.XVII.

${ }^{8} \mathrm{Ibid}$.

${ }^{9}$ En el ámbito de la crítica historicista, véase A. RICHARDSON and W. SCHWEITZER, Biblical Authority for Today, Philadelphia (Westminster), 1951, pp.241-244.

${ }^{10}$ En lo referente a la relación historia-interpretación bíblica, cfr. R. MORGAN and J. BARTON, Biblical Interpretation, Oxford University Press, 1988, pp.5-15. 
dos, el histórico-crítico y el historiográfico, son lo mismo, dado que su interés se fundamenta en la historia. Quienes utilizan esta metodología defienden que el significado y repercusión de la Biblia también deben hallarse en el estudio histórico ${ }^{11}$. Sin embargo, en su análisis de cómo y por qué un poeta debe leer la Biblia, Frye descarta ambos métodos.

En su estimación de que los métodos analíticos e historicistas no son aplicables en su estudio de la Biblia, Frye se deshace de las lenguas originales de aquélla. El interés por los textos bíblicos como documentos históricos significa, entre otras cosas, que las traducciones de la Biblia no reflejan el significado original de los textos, sino más bien las preocupaciones de los traductores y las exigencias de su situación histórica. No obstante, la preocupación confesa de Frye por la influencia de la Biblia en la literatura inglesa, no se basa en los primeros textos bíblicos traducidos, sino en las traducciones más populares de la Biblia, que para Frye es la Versión Autorizada de 1611, más conocida como la Biblia del King James. Mediante el análisis de la diferencia clara entre langue y langage, Frye ofrece fundamentos teóricos adicionales para lo que llama la realidad positiva de la traducción ${ }^{12}$, al tiempo que justifica su uso de la Biblia traducida. Mientras que los métodos analíticos e historicistas del estudio bíblico no ofrecen a Frye los recursos necesarios que precisa para su estudio de la Biblia, el enfoque tradicional del texto bíblico le otorga una estructura más aplicable: There remained the more traditional approaches of medieval typology and of certain forms of Reformation commentary. These were more congenial to me because they accepted the unity of the Bible as a postulate. They do tell us how the Bible can be intelligible to poets ${ }^{13}$.

${ }^{11}$ Los aspectos relacionados con el papel que la historia desempeña en la comprensión de la Biblia constituyen el mayor punto de fricción entre la mayoría de los estudiosos bíblicos y Frye. A.C. Hamilton indica que la critica negativa de The Great Code es atribuible a que Frye rechaza que la Biblia solo tiene una dimensión histórica secundaria y su defensa de que es "un gran código artístico", muy superior al que la historia pudiera revelar. Véase A.C. HAMILTON, "Northrop Frye on the Bible and Literature", Christianity and Literature (Spring, 1992), pp.225-276. Esta devaluación del papel de la historia en la crítica de Frye resulta lógica si tenemos en cuenta que su crítica literaria resalta la estructura total de la forma literaria, no su dimensión histórica. Para Frye, según señala en su Anatomy of Criticism, la literatura existe en el tiempo, pero también se extiende por un espacio conceptual, desde una especie de centro estratégico que la crítica puede localizar. Por lo tanto, ese espacio conceptual es, en muchos modos, ahistórico. Cada obra literaria, de cualquier momento histórico, participa en su estructura. La crítica literaria de Frye pretende localizar esta forma total de literatura.

${ }^{12}$ Northrop FRYE, The Great Code, ed. cit., p.4.

${ }^{13}$ Ibid., p.XVII. 


\section{J.L. Lanero}

Para Frye esta estructura tipológica de la Biblia refleja el principio que habitualmente se atribuye a San Agustín: "In the Old Testament the New Testament is concealed; in the New Testament the Old Testament is revealed". Everything that happens in the Old Testament is a 'type' or adumbration of something that happens in the New Testament, and the whole subject is therefore called typology ${ }^{14}$.

Los 'tipos' del Antiguo Testamento se convierten en manifiestos 'antitipos' en el Nuevo y la historia, en este sentido, se refiere a la realización de los acontecimientos prometidos o implícitos. Para Frye esta estructura revela el interés real de la historia por la Biblia. No es un documento de acontecimientos históricos sino más bien una clave para comprender el propio proceso histórico:What typology really is as a mode of thought, what it both assumes and leads to, is a theory of history, or more accurately of historical process: an assumption that there is some meaning and point to history ${ }^{15}$.

Para Frye, la tipología, como comprensión del proceso histórico, es un movimiento que avanza en dirección horizontal y que se complementa con un ascenso vertical ${ }^{16}$. La estructura de la tipología, por la que se anuncian los acontecimientos y posteriormente se materializan (movimiento horizontal), da a entender que la historia no es un mero conjunto de acontecimientos, sino más bien algo con un significado específico que trasciende los sucesos específicos (elevación vertical). Por ejemplo, en la espera del Mesías, su encarnación y el Apocalipsis, la Biblia señala un mundo eterno al que conducen todos los acontecimientos históricos. Sin este marco de referencia, el análisis histórico pierde contacto con el significado más profundo que guía a la humanidad: [biblical critics] are well aware that the Bible will only confuse and exasperate a historian who tries to treat it as history. One wonders why in that case their obsession with the Bible's historicity does not relax, so that other and more promising hypotheses could be examined. Trying to extract a credible historical residue from a mass of "mythical accretions" is a futile procedure, if the end in view is Biblical criticism rather than history ${ }^{17}$.

Los aspectos históricos secundarios de la Biblia son prescindibles para Frye, mientras que la estructura tipológica no ${ }^{18}$. Los acontecimientos bíblicos no se forjan por su correspondencia con sucesos his-

\footnotetext{
${ }^{14}$ Ibid., p.79.

15 Ibid., pp.80-81.

${ }^{16}$ Ibid., p.82.

${ }^{17}$ Ibid., p.42.

${ }^{18}$ Ibid., pp.40-41.
} 
tóricos reales, sino por una estructura tipológica herméticamente sellada. La tipología, en su conjunto, concede significado al propio proceso histórico.

Mientras que, sin lugar a dudas, la tipología está presente en el Nuevo Testamento, tal es el caso de la Epístola a los Romanos (5:14): Nevertheless death reigned from Adam to Moses, even over them that had not sinned after the similitude of Adam's transgression, who is the figure of him that was to come; y de la Primera Carta de Pedro (I, 3:20-1): Which sometime were disobedient, when once the longsuffering of God waited in the days of Noah, while the ark was a preparing, wherein few, that is, eight souls were saved by water. The like figure where unto even baptism doth also now save us (not the putting away of the filth of the flesh, but the answer of a good conscience toward God) by the resurrection of Jesus Christ..., en un principio, la tipología como modelo de interpretar la Biblia, la desarrollaron los Padres de la Iglesia para establecer la legitimidad del cristianismo (que Dios anticipó en la Biblia Hebrea) y la autoridad espiritual de la Biblia que se manifiesta en su simbolismo unificado. Sin embargo, Frye desea sacar esos elementos teológicos del uso que él hace de la tipología ${ }^{19}$. Del mismo modo que aparta de su estudio de la Biblia la investigación propia de los enfoques analítico e historicista, Frye también aleja su obra de la teología al afirmar que The Great Code no es una obra de investigación bíblica y mucho menos teológica ${ }^{20}$, aunque reconoce que el enfoque tradicional de la tipología bíblica es más apropiado para sus objetivos que la investigación bíblica; como: $A$ twentieth-century writer addressing twentieth-century readers, there seemed to me a need for a fresh and contemporary look at the Bible as an element in our present ad critical concerns ${ }^{21}$.

Parte de la visión fresca y contemporánea de la Biblia de Frye significa que los presupuestos originales de la teología, que desarrollaron los Padres de la Iglesia, deben ignorarse, lo que no impide una lectura tipológica de la estructura bíblica. A pesar de los orígenes y conexiones históricos, Frye cree que es posible eliminar los elementos teológicos del estudio tipológico de la Biblia porque el propio Nuevo Testamento hace uso de la tipología. En un párrafo de The Great Code dice: This typological way of reading the Bible is indicated too often and explicitly in the New Testament itself for us to be in any doubt that

${ }^{19}$ V. LEITCH, Cultural Criticism, Literary Theory, Poststructuralism, New York (Columbia University Press) 1992, p.69.

${ }^{20}$ Northrop FRYE, The Great Code, ed. cit., p.XI.

${ }^{21}$ Ibid., p.XVIII. 


\section{J.L. Lanero}

this is the 'right' way of reading it -'right' in the only sense that criticism can recognize, as the way that conforms to the intentionality of the book itself and to the conventions it assumes and requires ${ }^{22}$.

La tipología es apropiada para el interés de Frye por la Biblia como crítico literario que desea ocuparse del cómo y por qué un poeta ha de leerla, pero también lo es porque se ajusta a la propia intencionalidad de la misma. Ya en Anatomy of Criticism señala: We cannot trace the Bible back, even historically, to a time when its materials were not being shaped into a typological unity ${ }^{23}$.

Los que establecieron la forma canónica actual de la Biblia, ordenaron sus libros para que reflejara la unidad de una estructura tipo/antitipo. En consecuencia, la Biblia, según Frye, se ha leído como una unidad y, como tal, ha influido en la imaginación occidental ${ }^{24}$. Por lo tanto, Frye sólo se ocupa de la forma final de la Biblia, no de su composición histórica, ediciones a lo largo de la historia, fuentes, redacción o proceso canónico: The Bible does not, for all its miscellaneous content, present the appearance of having come into existence through an improbable series of accidents; and, while it is certainly the end product of a long a complex editorial process, the end product needs to be examined in its own right ${ }^{25}$.

Para Frye, pues, las razones teológicas de la estructura tipológica de la Biblia pueden obviarse si lo que interesa es la estructura final y cómo su unidad de imágenes ha influido en la literatura occidental.

La hermenéutica bíblica de Frye nos da cuenta detallada de lo que pensamos es su método para estudiar la Biblia. En resumen: su interés expreso por la Biblia es desde la perspectiva del crítico literario, que significa que intenta mostrar cómo y por qué un poeta debe leerla, lo que explica su desinterés por la investigación bíblica moderna y la utilización de un enfoque de tipología teológica más tradicional. Además, Frye intenta eliminar los elementos teológicos cristianos más antiguos de su uso de la tipología, desde la creencia de que el desarrollo original de este método, a cargo de los Padres de la Iglesia, no satisface las preocupaciones actuales. Por lo tanto, la tipología es la clave de la hermenéutica bíblica de Frye. La propia estructura de la Biblia nos muestra que no está pensada para ser leída como narración histórica de hechos, sino como un libro unificado que apunta a su pro-

\footnotetext{
${ }^{22}$ Ibid., pp.79-80.

${ }^{23}$ Northrop FRYE, Anatomy of Criticism: Four Essays, Princeton University Press, 1957, p.315.

${ }^{24}$ Northrop FRYE, The Great Code, ed. cit., p.XIII.

${ }^{25}$ Ibid., pp.XVII.
} 
pio interior. En su preocupación por satisfacer los acontecimientos prometidos o implícitos, la Biblia revela un interés por el proceso histórico, que no es lo mismo que decir un interés en documentar los acontecimientos históricos. Además, a lo largo de los siglos, muchos han sido los artistas que se han formado al amparo de esta comprensión tipológica de la Biblia y sus obras se aprecian más si somos sensibles a la tipología.

No obstante, la tipología como forma apropiada de lectura de la Biblia, puesto que se ajusta a la intencionalidad del libro en sí, tiene ramificaciones más amplias. Estas consideraciones tienen una implicación importante, por ejemplo, para la interpretación judaica de los textos bíblicos. Está claro que éstos cruzan por dos religiones interrelacionadas, pero diferentes al mismo tiempo. Y dado que la historia del antisemitismo que, al menos en parte, tiene sus raíces en la lectura cristiana de estos textos, cualquier lectura de la Biblia, como un todo unificado, debe considerarse desde una perspectiva más amplia, con el judaísmo en primer plano.

\section{III}

Es obvio que Frye es consciente de los presupuestos teológicos cristianos de la tipología, reconociendo la posición que percibe una inmensa mayoría: typology is a neglected subject (...) because it is assumed to be bound up with a doctrinaire adherence to Christianity ${ }^{26}$.

Y prosigue expresando claramente su interés por la tipología; para él es una especie de retórica y se puede estudiar de forma crítica como cualquier otra forma de retórica ${ }^{27}$. Dado su interés confeso por las imágenes bíblicas, Frye piensa que puede utilizar la tipología sin necesidad de negar una comprensión judaica de la Biblia. Al intentar mostrar que, objetivamente, la tipología se ajusta a la estructura intencionada de la Biblia, Frye afirma que la tipología también es aplicable al Antiguo Testamento: Typology in the Bible is by no means confined to the Christian version of the Bible: from the point of view of Judaism at least, the Old Testament is much more genuinely typological without the New Testament than with it. There are, in the first place, events in the Old Testament that are types of later events recorded also within the Old Testament ${ }^{28}$.

Y puesto que su interés lo centra en la Biblia como un todo unificado, Frye no entra en los detalles específicos de una lectura tipológi-

\footnotetext{
${ }^{26}$ Ibid., p.80.

${ }^{27}$ Ibid.

${ }^{28}$ Ibid., p.83.
} 


\section{J.L. Lanero}

ca judía de la Biblia Hebrea, independientemente del ejemplo de Aarón de construir un becerro de oro en la época del Libro del Éxodo (32:4): And he received [them] at their hand, and fashioned it with a graving tool, after he had made it a molten calf: and they said, These [be] thy gods, O Israel, which brought they up out of the land of Egypt, como un tipo de culto cismático establecido en el Israel del Norte, que también ideó becerros de oro, según se recoge en el Primer Libro de los Reyes (I, 12:28): Whereupon the king took counsel, and made two calves [of] gold, and said unto them, It is too much for you to go up to Jerusalem: behold thy goods, O Israel, which brought thee up out of the land of Egypt. El principal interés de Frye aquí es demostrar que su tipología no es teología cristiana. Quiere presentarnos un estudio literario de la estructura aparentemente objetiva de la Biblia. En concreto, pues, lo que debemos comprender es hasta qué punto Frye es capaz de apartar lo que él piensa que son los elementos tipológicos cristianos de su presunto método tipológico literario. Desde un punto de vista más amplio, también hemos de considerar la posibilidad de ese distanciamiento.

El primer aspecto a tener en cuenta es que, a través de su obra sobre la Biblia, Frye utiliza las palabras Antiguo Testamento y Nuevo Testamento para referirse a la Biblia. Los términos Biblia Hebrea y Biblia Cristiana se usan con frecuencia para rebajar la carga de los términos anteriores. A pesar de que Frye es consciente de la implicación de desprecio que destilan, usa los términos Antiguo y Nuevo porque para él reflejan la manera que la mayoría de los artistas occidentales han adoptado para leer la Biblia. Sin embargo, no sólo es una descripción del modo de leer la Biblia; para Frye también refleja la intencionalidad de la propia Biblia y, por lo tanto, es el precepto de la forma adecuada de leerla. Como ya hemos dicho, Frye afirma que esto es tan cierto para la Biblia Cristiana como para el Antiguo Testamento, a pesar de que su obra nos revela que la lectura apropiada de la Biblia debe considerar a Cristo como figura central. Por ejemplo: The Old Testament is concerned with the society of Israel; the New Testament is concerned with the individual Jesus. The society Israel, then, is the type of which the individual Jesus is the antitype. This relation of society to individual corresponds to certain elements of ordinary life: we belong to something before we are anything, and we have entered a specific social contract before birth (...). Social freedom, however essential, is general and approximate; real freedom is something that only the individual can experience ${ }^{29}$.

\footnotetext{
${ }^{29}$ Ibid., p.87.
} 
La libertad social del Antiguo Testamento, según Frye, está incompleta porque la libertad real sólo se obtiene de forma individual. El objetivo para él es que los individuos no sólo se identifiquen con la sociedad, sino también con el cuerpo social ${ }^{30}$. El modelo para esta libertad proviene de la idea que San Pablo tenía de su relación con Jesús: Paul, for example, says that he is dead as what we should call an ego, and that only Christ lives within him (Galatians 2:20, and similarly elsewhere) (...). Instead of an individual finding his fulfillment within a social body, however sacrosanct, the metaphor is reversed from a metaphor of integration into a wholly decentralized one, in which the total body is complete within each individual. The individual acquires his internal authority of the unity of the Logos, and it is this unity that makes him an individual ${ }^{31}$.

La hermenéutica de Frye revela una orientación cristológica en su fundamento, por mucho que use los términos "Antiguo" y "Nuevo" Testamentos. La mera posibilidad de una tipología que no sea cristiana es difícil de concebir. No cabe la menor duda de que la idea de recopilar y organizar los escritos de los primeros cristianos en un texto unificado, para ser leído con el Antiguo Testamento, la estimuló el dictado teológico cristiano. La creación del canon del Nuevo Testamento, que culmina en el siglo IV, fue un proceso largo y laborioso, resultado de presiones externas (Valentino, Marcionitas, Montanismo, Gnosticismo) y varios interrogantes planteados por la propia iglesia ${ }^{32}$. La creación de la Biblia, como Antiguo y Nuevo Testamento, está originada por, y destinada a, los cristianos. Frye sostiene que la intencionalidad de la Biblia es su lectura como un todo unificado, pero omite que esa postura sólo refleja las pretensiones cristianas.

Además, no es posible disociar la intención cristiana del origen bíblico de la forma en la que el mundo cristiano la ha leído. Los cristianos la han considerado un documento cristiano, lo que implica un An-

${ }^{30}$ Esto es lo que Frye denomina "metáfora real": "There is identification as as well as identification with. We identify $\mathrm{A}$ as $\mathrm{A}$ when we make it an individual of the class to which it belongs: that brown and green object outside my window I identify $a$ s a tree. When we combine these two forms of identification, and identify an individual with its class, we get an extremely powerful and subtle form of metaphor, which I sometimes call the royal metaphor, because it underlies one of the most symbolically pervasive of institutions, that of kingship. The function of the king is primarily to represent, for his subjects, the unity of their society in an individual form". Ibid.

${ }^{31}$ Ibid., p. 100.

${ }^{32}$ Véase B.M. METZGER, The Canon of the New Testament: Its Origin, Development and Significance, Oxford University Press, 1987, pp.75-112; 251-66. Véase también W.R. FARMER and D.M. FARKASFALVY, The Formation of the New Testament Canon, Toronto (Paulist) 1983. 


\section{J.L. Lanero}

tiguo y Nuevo Testamento. De manera abrumadora, se ha leído el Antiguo Testamento desde el Nuevo. En la actualidad, aunque un número cada vez mayor de lectores cristianos es consciente de que la lectura bíblica, como un Testamento Antiguo y Nuevo, conduce a sentimientos de rechazo del judaísmo, también se da cuenta de que la propia estructura de la Biblia imposibilita su lectura sin tener presente el hecho cristiano. Walter Brueggemann dice: It is enough for us to notice the ways in which Christian readers of the Old Testament have tended to run roughshod over the relatively playful and open inclination of the Old Testament rhetoric in order to serve the less tensive propensities of the Christian tradition (...). It is moreover likely that any Christian exposition (...) cannot finally resist such a temptation ${ }^{33}$.

Así pues, aunque Frye intenta comprender la estructura final de la Biblia, no puede evitar una lectura cristiana porque la propia Biblia es un documento cristiano. Cualquier estudio tipológico, incluido el de Frye, está entrelazado con los supuestos teológicos cristianos, dado que constituyó el aspecto más relevante de la construcción de la Biblia y su lectura posterior.

Está claro que la hermenéutica bíblica de Frye no es una investigación histórico-crítica. Es una obra de teología bíblica, pues defiende que la unidad final de la Biblia es una indicación de cómo debe leerse. Un estudio de los dos Testamentos de la Biblia, en el que el Antiguo se considera algo oculto que se nos revela en el Nuevo, con Cristo como elemento central de lo revelado, sólo nos puede dar una comprensión cristiana de la Biblia. Aunque la tipología refleja la forma en la que los poetas occidentales han leído la Biblia, también implica una formulación teológica.

Los parámetros de la lectura tipológica de Frye necesitan establecerse con firmeza. El primer objetivo de su obra sobre la Biblia es mostrar cómo y por qué un poeta debe leerla. Su explicación de la unidad de las imágenes bíblicas aclara buena parte de su atractivo para poetas y artistas. El segundo es más problemático. Hemos de tener cierta cautela con su idea de que la tipología refleja la forma en la que un poeta, o cualquiera, debería leer la Biblia, o la manera en la que la Biblia se nos presenta para que la leamos. A este precepto sólo se ajusta una Biblia hecha por cristianos para lectores cristianos. Es decir, se cristianiza la Biblia Hebrea bien por parte de los cristianos que establecieron el canon bíblico o por las interpretaciones posteriores, como la de Frye.

${ }^{33}$ W. BRUEGGEMANN, The theology of the Old Testament, ed. cit., pp.82-83. 
Por otro lado, puesto que la tipología bíblica de Frye no es sólo descriptiva de la historia de la lectura bíblica occidental, sino también normativa del modo en el que, según él, debemos leerla, es de fácil deducción que la lectura bíblica, como unidad tipológica, está asociada con la cristiandad y sigue siendo un ejercicio teológico cristiano.

Una parte del contexto para entender mejor el método tipológico de Frye tiene que ver con la palabra comprensión. La hermenéutica, según la formula Gerald Bruns, se ocupa, en primer lugar, de ver lo que sucede cuando intentamos encontrar sentido a algunos fenóme$\operatorname{nos}^{34}$. En nuestro caso, la hermenéutica puede ayudar a concentrarnos en cómo la posición metodológica de Frye conforma su enfoque del significado. Como hemos visto, él mismo cree que su método incrementa la comprensión de la intencionalidad de la Biblia porque su significado se libera de las cadenas doctrinales e históricas y de desempeñar el papel de fuente unificada y viva para la imaginación artística occidental. Igualmente, Frye fue consciente de que su enfoque del material bíblico tenía implicaciones hermenéuticas, reconociendo la influencia de Gadamer y Ricoeur en The Great Code, aunque no siempre de la manera con la que ellos estarían de acuerdo ${ }^{35}$. Mientras que conceptos tales como la fore-conception of completeness de Gadamer, sólo por citar un ejemplo palmario, tiene frecuentes similitudes y corolarios en las teorías de Frye ${ }^{36}$, el lugar de la hermenéutica para Gadamer como sistema de conocimiento no es el mismo que el de Frye. En un párrafo especialmente pertinente para este estudio del método de Frye, Gadamer dice: Hermeneutics must start from the position that a person seeking to understand something has a bond to the subject matter that comes into language through the traditionary text and has, or acquires, a connection with the tradition from which the text speaks. On the other hand, hermeneutical consciousness is aware that its bond to this subject matter does not consist in some selfevident, unquestioned unanimity, as is the case with the unbroken stream of tradition (...). Here too there is a tension. It is in the play between the traditionary text's strangeness and familiarity to us, between being a historically intended, distanciated object and belonging to a tradition. The true locus of hermeneutics is this in-between ${ }^{37}$.

${ }^{34}$ Gerald BRUNS, Hermeneutics Ancient and Modern, New Haven (Yale University Press) 1995 , p.8.

${ }^{35}$ Northrop FRYE, The Great Code, ed. cit., p.xix.

${ }^{36}$ Sobre la "fore-conception of completeness", véase H.G. GADAMER, Truth and Method, Trans. J.C. WEINSHEIMER and D.G. MARSHALL, 2nd revised edition, New York (Crossroad) 1993, pp.265-266 y 293-294.

${ }^{37}$ Ibid., p. 295. 


\section{J.L. Lanero}

En el intento de Frye de distanciarse del historicismo específico de la Biblia, reduce a la mitad la tensión que nos concede una comprensión de la totalidad compleja del texto. Aunque es lamentable, no resulta fatal, pues Frye no es un hermenéutico del que pueda decirse que su objetivo sea, de manera intencionada, abarcar tan sólo la mitad de la tensión. El problema es que Frye es incapaz de dar forma consistente a sus presupuestos y opciones metodológicos al interpretar los textos bíblicos a su particular manera. El resultado, forzosamente, han sido numerosas lecturas equivocadas de la obra de Frye, positivas y negativas, pues sus reflexiones metodológicas no han sido plenamente comprendidas ni puestas en contexto ${ }^{38}$. Según hemos visto, Frye no es capaz de ofrecer un enfoque estrictamente literario de la Biblia, pero resalta la unidad de las imágenes bíblicas de tal forma, que resulta útil para un cristiano y/o un artista. Esa dificultad en localizar los propios presupuestos es un hecho que resulta cierto para el propio Gadamer: Given the intermediate position in which hermeneutics operates, it follows that its work is not to develop a procedure of understanding, but to clarify the conditions in which understanding takes place. But these conditions do not amount to a 'procedure' or method which the interpreter must of himself bring to bear on the text; rather, they must be given. The prejudices and fore-meanings that occupy the interpreter's consciousness are not at his free disposal. He cannot separate in advance the productive prejudices that enable understanding from the prejudices that hinder it and lead to misunderstandings $s^{39}$.

\section{IV}

Si queremos entender cómo el método de Frye procura crear un significado, hemos de hacer emerger aquellos presignificados que Frye no utilizó. Sólo así su obra bíblica puede considerarse en el contexto apropiado: una lectura literaria de la Biblia como unidad imaginaria, al asumir la tipología como intención acertada de la propia Biblia, que se basa en presupuestos teológicos cristianos. El enfoque claramente literario desde el que Frye estudia la Biblia no es histórico, sino tipológico y cristiano; ello implica que ese marco inevitable debe estar presente en la evaluación de cómo la posición concreta de Frye

${ }^{38}$ Las reacciones a la publicación de The Great Code fueron inmediatas y de corta vida. R. DENHAM en Northrop Frye: An Annotated Bibliography of Primary and Secondary Sources, Toronto University Press, 1987, cita 135 recensiones de The Great Code, aunque los estudios bíblicos de Frye tuvieron escasa influencia.

${ }^{39}$ H.G. GADAMER, Truth and Method, ed. cit., p. 265. 
crea un significado en la influencia de la Biblia, su interacción, en su tensión con la historia, la teología, el arte y la traducción. 